УДК 619:591.133.15:542.05

doi: $10.36359 /$ scivp.2019-20-2.50

\title{
НОВИЙ МІНЕРАЛЬНИЙ ПРЕПАРАТ ДЛЯ ВЕТЕРИНАРНОЇ ПРАКТИКИ «КАЛЬФОМІН»
}

\author{
P. М. Сачук ${ }^{l}$, канд. вет. наук, \\ С. В. Жигалюк ${ }^{1}$, науковий співробітник, \\ Я. С. Стравськийㄹ, д-р вет. наук, с. н. с., \\ О. І. Чайковська ${ }^{3}$, канд. біол. наук, с. н. с., \\ О. А. Качараба 4 , канд. вет. наук, доцент, \\ Н. П. Болтик ${ }^{5}$ канд. біол. наук
}
${ }^{1}$ Дослідна станція епізоотології Інституту ветеринарної медицини НААН, вул. Князя Володимира, 16/18, м. Рівне, 33028, Україна

${ }^{2}$ Тернопільський національний медичний університет імені І. Я. Горбачевського

МО3 України,

майдан Волі, 1, м. Тернопіль, 46002, Україна

${ }^{3}$ Державний науково-дослідний контрольний інститут ветеринарних препаратів та кормових добавок, вул. Донецька, 11, 79000, м. Львів, Україна

${ }^{4}$ Львівський національний університет ветеринарної медицини та біотехнологій імені. С. 3. Гжицького,

вул. Пекарська 50, м. Львів, 79010, Україна

${ }^{5}$ Тернопільська дослідна станція Інституту ветеринарної ветеринарної медицини НААН, вул. Тролейбусна, 12, м. Тернопіль, 46027, Україна

У статті представлено нову фармацевтичну композицію "Кальфомін», щзо включає макро- та мікроелементи у вигляді водорозчинних солей, а саме: Кальиій, Фосфор, Магній, Натрій, Калій, Ферум, Манган, Цинк, Кобальт та Купрум. Також до складу препарату входять незамінні амінокислоти - метіонін та лізин. Препарат застосовують для лікування та профілактики захворювань корів, свиней, овець $і$ кіз, пов'язаних з порушенням метаболізму перерахованих нутрієнтів (післяродового парезу, рахіту у молодих тварин, остеомаляиії у старих тварин). Лікарський засіб ефективний при алергіях, токсикозах, післяродовій гемоглобінурії, плямистій хворобі, кропив'янці, екзантемі, геморагічному діатезі, гематурї $i$ міоглобінурії; парезі внаслідок дефіциту Кальциію або Фосфору різної етіології. Рекомендовано “Кальфомін” в якості допоміжної терапії при отруєннях Свинщем, Фтором або Щавлевою кислотою, а для птиці для покращення яйценосності. Препарат застосовують для збільшення приросту живої ваги тварин на відгодівлі, тощо.

При введенні лабораторним тваринам у шлунок, внутрішньоочеревно і підшкірно, встановлено, що препарат належить до IV класу токсичності згідно СОУ 85.2-37-736:2011 та ГОСТ 12.1.007-76, тобто відноситься до малотоксичних речовин. Отримано дані про суттєве підвищення уже на 3-тю добу загального Кальцію, неорганічного Фосфору, Цинку та Купруму у сироватиі крові отелених корів, яким перорально задавали “Кальфомін”. А на 14ту добу активність цих елементів уже була в межах фізіологічних норм. Пероральне введення коровам "Кальфоміну” в дозі 30 мл на 100 кг маси тіла протягом 10 діб після отелу запобігає післяродовому парезу. “Кальфомін” представляє інтерес для ветеринарної медицини і тому дочільно продовжити його подальще клінічне дослідження і стандартизувати показники його якості. 
Ключові слова: ОРАЛЬНИЙ ПРЕПАРАТ, МІНЕРАЛИ, АМІНОКИСЛОТИ, “КАЛЬФОМІН”, ПІСЛЯРОДОВИЙ ПАРЕЗ.

Збалансована годівля є запорукою здоров'я тварин, тривалості їх продуктивного використання, що в кінцевому рахунку визначає прибутковість галузі. А мінеральна складова раціонів, на рівні 3 органічними речовинами особливо важливі у годівлі сільськогосподарських тварин, які обмежені у вільному виборі кормів. Нестача, або дисбаланс окремих елементів, порушення їх співвідношення у раціоні знижують прирости маси тварин, спричиняють тяжкі захворювання, що не рідко призводять до загибелі при відсутності своєчасного лікування $[1,2]$.

Техногенне забруднення довкілля, в тому числі і радіоактивне, неконтрольоване використання мінеральних добрив, нераціональні агротехнічні заходи значно посилюють природній дефіцит біогенних мікроелементів, сприяючи розвитку комплексних мікроелементозів тварин. Забезпечення худоби у господарствах Західного регіону України мінеральною складовою, характеризується їх дефіцитом у водах, грунтах, кормах, а звідси - й раціонах тварин. Зовнішніми проявами захворювань обміну речовин $\epsilon$ дерматопатії, депігментації волосяного покриву, анемічність видимих слизових оболонок, порушення пропорційності будови тіла тварин, деформації копит. Системними проявами мікро-, макроелементозів $€$ порушення гемопоезу, імунної резистентності організму, розлади відтворювальної функції, затримки росту і розвитку у перинатальний та постнатальний періоди і низька продуктивність тварин $[1,3,4]$.

В основі профілактики і лікування хвороб обміну речовин повинні бути регулярні обстеження фізіологічного стану поголів 'я, аналіз мікро- та макроелементозного складу води, кормів конкретного господарства 3 подальшою корекцією раціону годівлі шляхом підбору відповідних кормових добавок. Особливо актуальною $є$ така практика при веденні тваринництва у Зоні Західного Полісся, де виявлено нестачу життєво необхідних металів у воді, грунтах, а відповідно і в рослинних кормах. Наші дослідження мінерального складу кормової бази у господарствах регіону виявили дефіцит від норми: Цинку на рівні 33,0-39,9\%; Марганцю - 47,9-51,0 \%; Міді - 21,5-30,5 \% та Кобальту - 40,0-45,2 \%, що потребує пошуку і впровадження нових лікувально-профілактичних засобів [2].

Мета роботи полягала у розробленні нового мінерального препарату - “Кальфомін” для лікування та профілактики захворювань тварин, пов'язаних 3 порушеннях метаболізму Кальцію, Фосфору, Магнію, Натрію, Калію, Заліза, Марганцю, Цинку, Кобальту та Купруму у тварин.

Матеріали і методи. Проаналізувавши етіопатогенетичні та клінічні фактори розвитку післяродових метаболічних захворювань у тварин, в якості комплексного лікарського засобу обрано фармацевтичну композицію для орального застосування. У складі препарату є Кальцій, Фосфор, Магній, Натрій, Калій, Ферум, Манган, Цинк, Кобальт і Купрум та незамінні амінокислоти - метіонін та лізин. Розробник препарату ПП «Біофарм», 22300, Україна, Вінницька область, Літинський район, смт. Літин, вул. Богдана Хмельницького, 37 спільно 3 Дослідною станцією епізоотології IBM НААН, 33028, Україна, м. Рівне, вул. Князя Володимира, 16/18. Виробництво планується на потужностях: ТзОВ “ДЕВІЕ”, 22300, Україна, Вінницька область, Літинський район, смт. Літин, вул. Богдана Хмельницького, 37.

Експериментальні, доклінічні та клінічні досліження проведені відповідно до законодавчої і нормативно-правової бази доказової ветеринарної медицини $[5,6]$.

Визначення у сироватках крові вмісту загального Кальцію, неорганічного Фосфору, Цинку та Купруму проведено спектрофотометрично на атомно-абсорбційному спектрофотометрі C-115M1 у лабораторії експериментально-аналітичних методів досліджень Дослідної станції епізоотології ІВМ НААН $[7,8]$.

Статистичну обробку результатів виконано за загальноприйнятою методикою [9]. 
Результати й обговорення. При обгрунтуванні складу нового мінерального препарату “Кальфомін” враховано літературні дані, власний практичний досвід та результати вивчення вмісту неорганічних елементів у воді, кормах і біохімічних досліджень крові тварин [10]. Найбільш доцільною є комбінація компонентів у співвідношенні мас наведених в таблиці.

Склад препарату “Кальфоміну”, мас. \%

\begin{tabular}{|l|c|}
\hline \multicolumn{1}{|c|}{ Компоненти } & Мас. \% \\
\hline Магнію хлорид шестиводний & 2,67 \\
\hline Фосфорний ангідрид & 24,20 \\
\hline Кальцію хлорид & 11,27 \\
\hline Калію хлорид & 0,20 \\
\hline Натрію хлорид & 0,40 \\
\hline Ферум (III) хлорид шестиводний & 0,57 \\
\hline Цинку хлорид & 0,13 \\
\hline Марганцю (II) хлорид чотириводний & 0,17 \\
\hline Кобальту хлорид шестиводний & 0,09 \\
\hline Купрум (ІІ) хлорид п`ятиводний & 0,07 \\
\hline Лізин & 0,62 \\
\hline Метіонін & 1,00 \\
\hline Вода дистильована & 58,60 \\
\hline
\end{tabular}

В експерименті на лабораторних тваринах підтверджено безпечність складу і дозувань лікарського засобу “Кальфомін” на основі водорозчинних солей Кальцію, Фосфору, Магнію, Натрію, Калію, Феруму, Мангану, Цинку, Кобальту та Купруму та незамінних амінокислот метіоніну і лізину. За дослідженнями гострої і хронічної токсичності та алергізуючої дії препарат віднесено до IV класу токсичності згідно СОУ 85.2-37-736:2011 та ГОСТу 12.1.00776, тобто до малотоксичних речовин при введенні лабораторним тваринам як у шлунок, так i внутрішньоочеревинно і підшкірно.

В якості піддослідних об'єктів використовували різні види сільськогосподарських тварин (велика та дрібна рогата худоба, свині, птиця) з післяродовими парезами, рахітами, остеомаляціями та відставанням у рості.

Препарат пройшов широкі клінічні випробування на 195-ти сільськогосподарських тваринах (велика рогата худоба, коні, вівці, кози, свині, птиця) з ознаками порушення метаболізму мікро-, макроелементів. Зокрема неодноразово апробований при проявах гіпокальціємії (післяродовий парез, рахіт у молодих тварин, остеомаляція у старих тварин) та алергіях. Відмічено високу лікувальну ефективність мінерального препарату “Кальфомін” при профілактиці післяродового парезу отелених корів у ФГ “Мрія" Рівненської області. Позитивний вплив орального використання препарату “Кальфомін” в дозі 30 мл на 100 кг маси тіла, застосованого протягом 10 діб після отелу, позначився на концентрації загального Кальцію, неорагнічного Фосфору, Цинку та Купруму в крові. Проведене нами вивчення рівня загального Кальцію показало його достовірне, хоча і помірне підвищення у порівнянні 3 показниками до застосування препарату, а саме на 6-ту добу вміст елементу в крові корів зріс

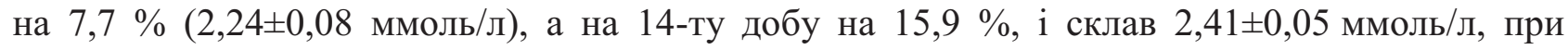

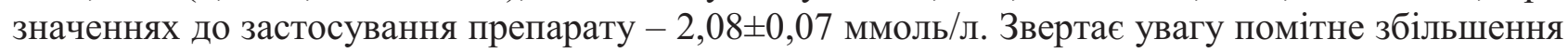
вмісту неорганічного Фосфору, на 3-тю добу концентрація його зросла на 27,7 \%

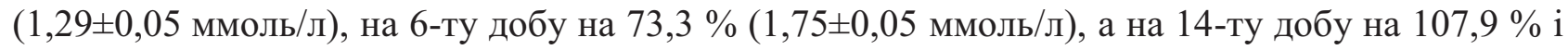

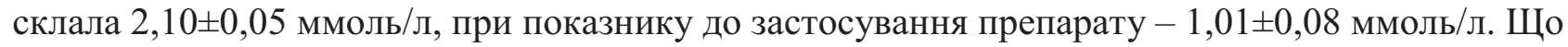
стосується вмісту мікроелементів Цинку та Купруму, то на 3-тю добу показники відповідно

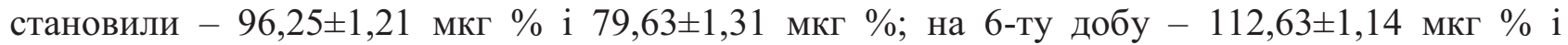

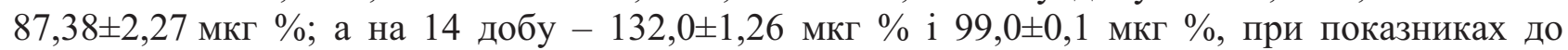

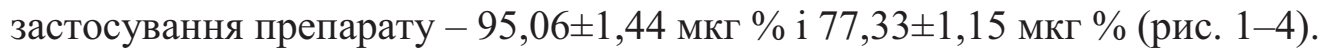




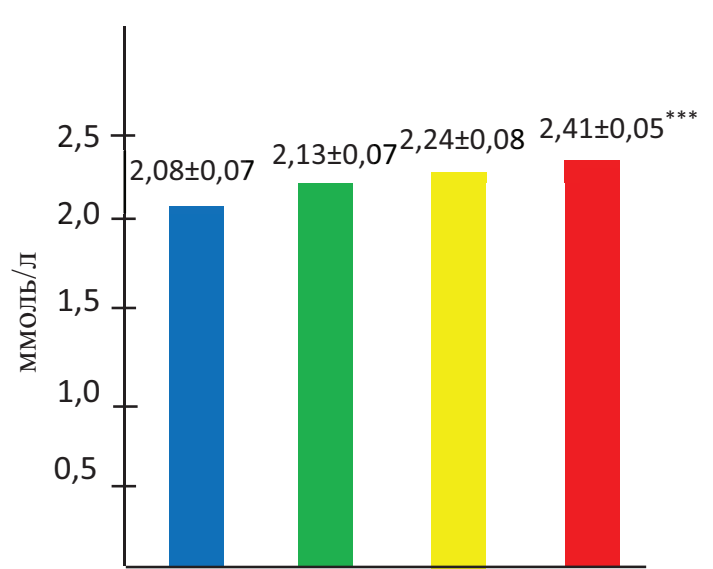

Puc. 1. Вміст кальцію в сироватці крові корів $(\mathrm{M} \pm \mathrm{m} ; \mathrm{n}=8)$

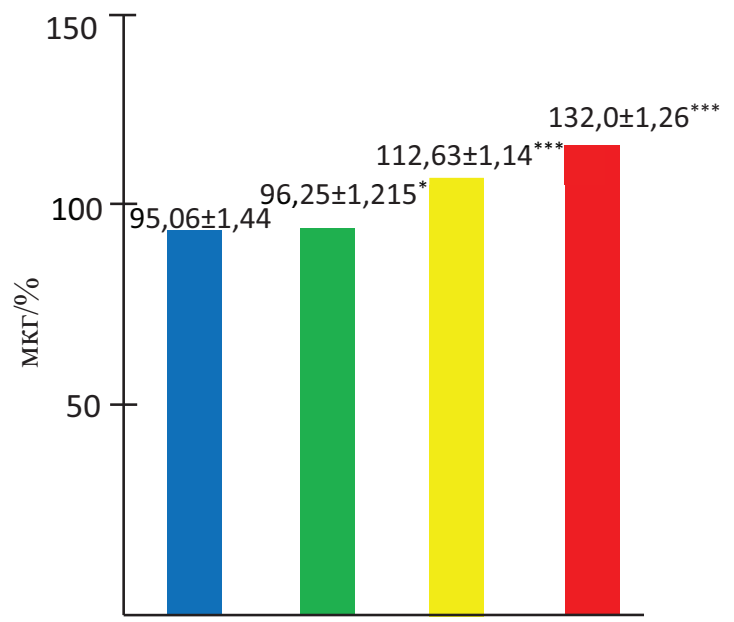

Puc. 3. Вміст цинку в сироватці крові корів $(\mathrm{M} \pm \mathrm{m} ; \mathrm{n}=8)$

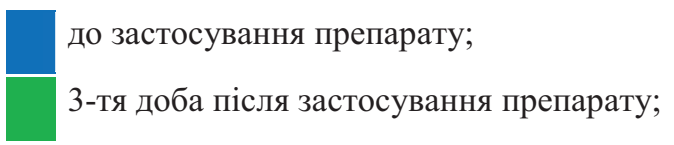

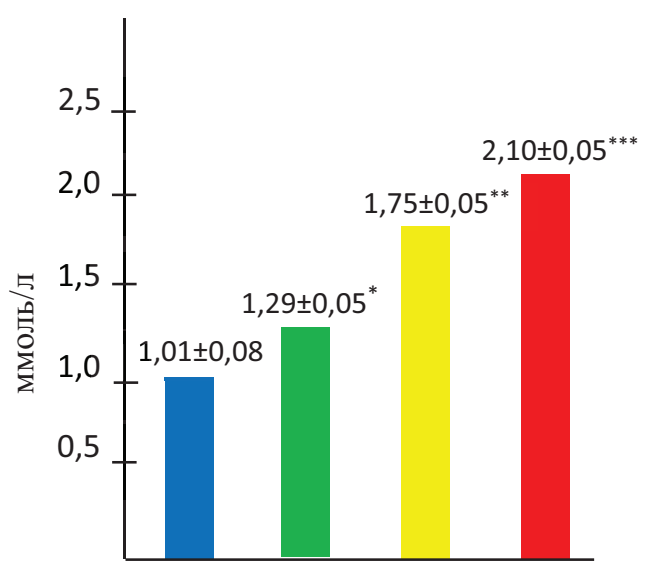

Рuc. 2. Вміст фосфору в сироватці крові корів $(\mathrm{M} \pm \mathrm{m} ; \mathrm{n}=8)$

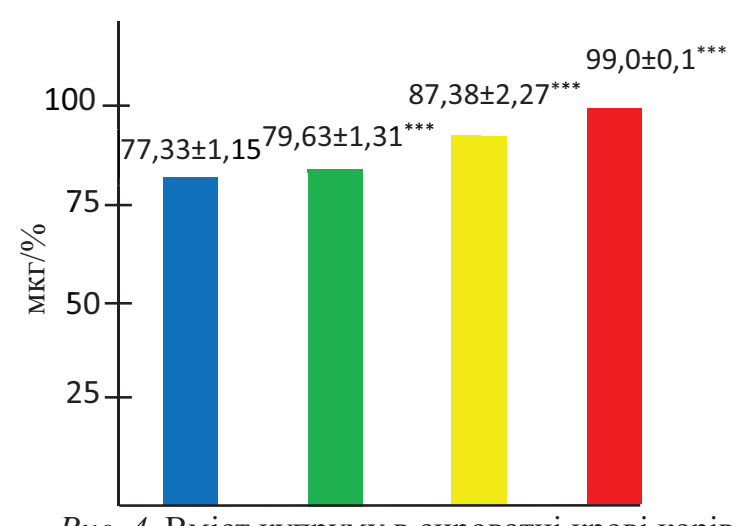

Puc. 4. Вміст купруму в сироватці крові корів $(\mathrm{M} \pm \mathrm{m} ; \mathrm{n}=8)$

6-та доба після застосування препарату;

14-та доба після застосування препарату.

Примітка: на рисунках позначено вірогідні різниці: ${ }^{*} \mathrm{p}<0,05 ;{ }^{* *} \mathrm{p}<0,01 ;{ }^{* * *} \mathrm{p}<0,001$ між показниками до застосування препарату.

Таким чином, отримані дані дають підставу вважати, що корекція мінерального живлення піддослідних корів шляхом додавання до раціону “Кальфоміну” активізує перебіг відновних процесів у крові щодо Кальцію, Фосфору, Цинку та Купруму. Крім того, встановлено, що завдяки оральному введенню “Кальфоміну” протягом 10 діб після отелення відсутні випадки післяродового парезу, а концентація Кальцію, Фосфору, Цинку та Купруму в крові корів зберігалася у межах фізіологічних норм протягом 14 діб.

Результати випробувань знайшли відображення у проекті листівки-вкладки до застосування препарату, яка включає обов'язкові статті (опис, склад, фармакологічні властивості, застосування, дозування, протипоказання, вид лікарської форми та зберігання). 


\section{Листівка-вкладка щодо застосування фармацевтичної композиції "Кальфомін"}

(розчин для перорального застосування)

Кальфомін - комплексний оральний препарат, який застосовується для корекції та нормалізації обмінних процесів, в основі яких лежить порушення мінерального обміну. Іони Кальцію регулюють проникність біологічних мембран, забезпечуючи нервово-м'язову провідність. Дефіцит іонів Кальцію і тканинних рідин підвищує збудливість нервових вузлів, що може призвести до тетанії. Крім того, Кальцій впливає на колоїдний стан білків шляхом зниження їх дисперсії, що призводить до зменшення проникності кровоносних судин. Кальцій стимулює серцево-судинну систему і при внутрішньовенному введенні симпатичну частину вегетативної нервової системи, збільшуючи вивільнення адреналіну; наявний у процесі згортання крові. Фосфор спільно з Кальцієм впливає на розвиток кісток і зубів; входить до складу фосфоліпідів, фосфопротеїнів, нуклеїнових кислот і багатьох коферментів. Неорганічні первинні і вторинні фосфати впливають на підтримку кислотно-лужного балансу, відіграють важливу роль в метаболізмі вуглеводів. Магній - внутрішньоклітинний іон, необхідний для активації багатьох ферментів, зокрема тих, які беруть участь у збереженні енергії у вигляді фосфатних сполук. Магній регулює вивільнення ацетилхоліну з рухових кінцевих пластинок, впливає на м'язову збудливість. Натрій - катіон, який бере участь у підтриманні осмотичного тиску, у побудові нових клітин і тканин, у складних фізико-хімічних процесах обміну речовин. Він є комплексним компонентом буферних систем, що підтримує кислотно-лужну рівновагу в організмі. Стимулює імунобіологічні процеси, підсилює лейкоцитоз, збільшує кількість тромбоцитів. Солі Натрію тісно пов'язані з білковим, жировим, вуглеводним та водним обмінами, впливають на сенсибілізацію організму, входять до складу електролітів. Натрій у взаємодії з калієм бере участь у процесах передачі імпульсів у нервову тканину, впливає на серцево-судинну систему. Калій - основний катіон клітинного середовища. Бере активну участь у підтриманні осмотичного тиску, кислотно-лужної рівноваги, а також в усіх процесах обміну речовин. За участі іонів Калію, що утримуються в еритроцитах, відбувається перенесення кисню гемоглобіном. Ферум - елемент, що входить до складу гемоглобіну і деяких дихальних ферментів. Гемоглобін утворюється в кістковому мозку за участі вітаміну $\mathrm{B}_{12}$, Купруму та інших елементів. При розщепленні гемоглобіну Ферум не виводиться 3 організму, а відкладається в печінці і селезінці та може знову використовуватися для синтезу гемоглобіну чи на інші потреби. Марганець є важливим елементом у живленні. Бере участь у процесах обміну речовин, активує ряд ферментів, впливає на обмін азотних речовин, Кальцію й Фосфору. Сприяє посиленню росту тварин, впливає на кровотворення та обмін вуглеводів, бере активну участь в окисно-відновних процесах, тканинному диханні, посилює дію вітамінів $\mathrm{C}, \mathrm{B}$, тісно пов'язаний із відтворювальними функціями тварин. Цинк за кількісним складом в організмі тварин - другий після заліза. Бере участь у процесах дихання, є каталізатором в окисно-відновних процесах, підвищує активність вітамінів і посилює фагоцитоз, впливає на процеси запліднення й розмноження, активує гормон інсулін, кишкову фосфатазу, регулює активність кальцію й міді, послаблює гіпертензивний вплив адреналіну. Цинк значно впливає на основні життєві процеси: кровотворення, ріст та розвиток організму, обмін вуглеводів, білків і жирів, енергетичний обмін. Кобальт бере участь у кровотворенні, безпосередньо впливає на кровотворні функції кісткового мозку, прискорює синтез гемоглобіну, підвищує засвоєння заліза в організмі. Впливає на процеси обміну речовин і росту тварин, синтез і активування деяких ферментів, входить до складу вітаміну $\mathrm{B}_{2}$, сприяє кращому засвоєнню азоту і підвищує біосинтез білків, позитивно впливає на плодючість і молочність маток. Купрум - незамінний мікроелемент, необхідний для нормальної життєдіяльності тварин і 
рослин. Найважливішою функцією є сприяння кровотворенню через участь у перетворенні заліза в органічно зв'язану форму і прискорення синтезу гемоглобіну. Впливає на ріст, розвиток, відтворення, обмін, фагоцитарну активність лейкоцитів. Входить до складу багатьох білків, активує ферменти, бере участь у біосинтезі гормонів і вітамінів, регулюванні водного $і$ газо-енергетичного обміну, підвищує детоксикаційні функції печінки, має пряме відношення до функцій розмноження.

Метіонін і лізин - незамінні амінокислоти. Метіонін необхідний для підтримки росту і азотистої рівноваги організму. В організмі не синтезується, повинен поступати з білковою їжею. Бере участь у синтезі холіну, адреналіну, креатину, цистеїну та інших біологічно важливих сполук, сприяє активації гормонів, вітамінів, ферментів, служить джерелом сірки для організму. Лізин необхідний для синтезу специфічних білків і білкового обміну.

\section{Застосування}

Лікування та профілактика захворювань тварин, пов'язаних з порушенням метаболізму Кальцію, Фосфору, Магнію, Натрію, Калію, Заліза, Марганцю, Цинку, Кобальту та Купруму: гіпокальціємія (післяродовий парез, рахіт у молодих тварин, остеомаляція у старих тварин); алергія, токсикоз, післяродова гемоглобінурія, плямиста хвороба, кропив'янка, екзантема, геморагічний діатез, гематурія і міоглобінурія; парез внаслідок дефіциту кальцію або фосфору різної етіології; допоміжна терапія при отруєннях свинцем, фтором або щавлевою кислотою; птиці для покращення яйценосності. Препарат застосовують для збільшення приросту живої ваги тварин на відгодівлі, тощо.

\section{Дозування}

“Кальфомін” застосовують як з кормом, так і з водою протягом 7-14 діб. Добова норма препарату:

$$
\begin{aligned}
& \text { ВРX-20-30 мл / } 100 \text { кг; } \\
& \text { телята - } 15 \text { мл / гол.; } \\
& \text { свині - 10-15 мл / гол.; } \\
& \text { поросята - 5-10 мл / гол.; } \\
& \text { кози - 5-10 мл / гол., } \\
& \text { птиия - 0,5-1 мл / гол. з кормом; }
\end{aligned}
$$

курчата - 0,1-0,3 мл / гол, з водою випоювати з розрахунку 2,5-5 л. на 1000 л води.

\section{Протипоказання}

Індивідуальна чутливість до компонентів препарату. 3 особливою обережністю застосовують тваринам із захворюваннями серця, нирок. Не застосовувати одночасно 3 препаратами дигіталісу, оскільки це може викликати порушення функції серця, або його блокаду! Одночасне застосування препаратів кальцію і вітаміну D або його аналогів може призвести до гіперкальціємії.

\section{Застереження}

Продукція тваринництва використовується без обмежень.

При роботі з препаратом потрібно дотримуватись правил особистої гігієни і техніки безпеки, передбачених при роботі з ветеринарними препаратами. Під час роботи з препаратом забороняється курити, приймати їжу або пити рідину.

\section{Форма випуску}

Флакони по 100 мл, полімерні контейнери по 5 л.

\section{Зберігання}

Сухе, темне, недоступне для дітей місце при температурі 5-25 ${ }^{\circ} \mathrm{C}$. Препарат зберігати окремо від харчових продуктів, напоїв, у тому числі від корму для тварин.

Термін придатності - 2 роки 3 дати виготовлення. Після першого відбору препарат необхідно використати протягом 28 діб за умови зберігання в оригінальній упаковці при температурі від +4 до $+8{ }^{\circ} \mathrm{C}$.

Для застосування у ветеринарній медицині! 


\section{Власник ресстраційного посвідчення:}

\section{ПП "Біофарм"}

22300, Україна, Вінницька область, Літинський район, смт. Літин, вул. Богдана Хмельницького, 37. Тел./факс (04347) 2-21-44.

\section{Виробник готового продукту:}

ТОВ “ДЕВІЕ” 22300, Україна, Вінницька область, Літинський район, смт. Літин, вул. Богдана Хмельницького, 37. Тел./факс (04347) 2-21-44.

\section{В И С Н О В К И}

1. Створено фармацевтичну композицію у вигляді препарату для перорального застосування, який містить Кальцій, Фосфор, Магній, Натрій, Калій, Ферум, Манган, Цинк, Кобальт та Купрум і незамінні амінокислоти - метіонін та лізин. Препарат застосовують для лікування та профілактики захворювань корів, свиней, овець і кіз, пов'язаних з порушенням метаболізму перерахованих нутрієнтів.

2. Встановлено, що препарат належить до IV класу токсичності згідно з СОУ 85.2-37736:2011 та ГОСТ 12.1.007-76, тобто відноситься до малотоксичних речовин при введенні лабораторним тваринам як у шлунок, так і внутрішньоочеревинно і підшкірно.

3. Встановлено, що в сироватці крові отелених корів, яким перорально задавали "Кальфомін”, уже на 3-тю добу відмічалося суттєве підвищення загального Кальцію, неорганічного Фосфору, Цинку та Купруму, а на 14-ту добу активність цих елементів була в межах фізіологічних норм.

4. Пероральне введення коровам препарату “Кальфомін” в дозі 30 мл на 100 кг маси тіла протягом 10 діб після отелу запобігає післяродовому парезу.

5. Розроблено проект листівки-вкладки для “Кальфоміну” у практиці ветеринарної медицини.

Перспективи досліджень. Перспектива подальших досліджень стосуватиметься використаня препарату “Кальфомін” для розробки профілактичних заходів акушерської патології та буде визначено ефективність їх застосування.

\section{A NEW MINERAL DRUG FOR VETERINARY PRACTICE “CALFOMIN”}

R. M. Sachuk ${ }^{1}$, S. V. Zhyhalyuk ${ }^{1}$, Ya. S. Stravsky ${ }^{2}$, A. I. Chaykovska ${ }^{3}$, O. A. Katsaraba ${ }^{4}$, N. P. Boltyk

${ }^{1}$ Research Epizootology Station IVM NAAN

st. Knyazya Volodymyra 16/18, Rivne, 33028, Ukraine

${ }^{2}$ I. Gorbachevsky Ternopil National Medical University maidan Voli, 1, Ternopil, 46002, Ukraine

${ }^{3}$ State Scientific-Research Control Institute for Veterinary Medicinal Products and Feed Additives, st. Donetsk, 11, Lviv, 79000, Ukraine

${ }^{4}$ Stepan Gzhytskyi National University of Veterinary Medicine and Biotechnologies, st. Pekarska 50, Lviv, 79010, Ukraine

${ }^{5}$ Ternopil Research Station, Institute of Veterinary Medicine, NAAN, st. Troleybusna, 12, Ternopil, 46027, Ukraine

\section{S U M M A R Y}

A new pharmaceutical composition "Calfomin", that includes macro-and trace elements in the form of water-soluble salts, namely Calcium, Phosphorus, Magnesium, Natrium, Potassium, Ferum, Mangan, Zinc, Cobalt and Kuprom, is presented in the article. Also drug include essential amino acids 
- methionine and lysine. The drug is used for the treatment and prevention of diseases of cows, pigs, sheep and goats, associated with metabolic disorders of the listed nutrients (postpartum paresis, rachitis in young animals, osteomalacia in the elderly animals). The drug is effective in allergies, toxicosis, postpartum hemoglobinuria, spotted disease, hives, exanthema, hemorrhagic diathesis, hematuria and myoglobinuria; paresis due to a deficit of Calcium or Phosphorus of different etiology. "Calfomin" is recommended as an auxiliary therapy for Poisoning with Lead, Fluorine or Acidic Acid, and for poultry to improve egg-laying. The drug is used to increase the weight gain of animals on fattening, etc.

When administered to laboratory animals in the stomach, intraperitoneally and subcutaneously, it is established that the drug belongs to the IV class toxicity according to the GCM 85.2-37-736: 2011 and GOST 12.1.007-76, that is, it belongs to low-toxic substances. The data on the significant increase in Calcium, inorganic Phosphorus, Zinc and Kuprum in the serum of domesticated cows, which were orally called "Calfomin", were obtained on the 3rd day. And on the 14th day the activity of these elements was already within the limits of physiological norms. Oral administration to cows "Calfomin" in a dose of $30 \mathrm{ml}$ per $100 \mathrm{~kg}$ of body weight for 10 days after a calving prevents postpartum paresis. "Calfomin" is of interest to veterinary medicine, and therefore it is expedient to continue its further clinical study and standardize the indicators of its quality.

Keywords: ORAL PREPARATION, MINERALS, AMINO ACIDS, "CALFOMINE", POSTPARTUM PARESIS.

\title{
НОВЫЙ МИНЕРАЛЬНЫЙ ПРЕПАРАТ ДЛЯ ВЕТЕРИНАРНОЙ ПРАКТИКИ “КАЛЬФОМИН"
}

\author{
P. М. Сачук', С.В. Жигалюк ${ }^{1}$, Я. С. Стравский², А. И. Чайковская', \\ О. А. Качараба ${ }^{4}$, Н. П. Болтик ${ }^{5}$
}

${ }^{1}$ Опытная станция эпизоотологии Института ветеринарной медицины НАAН,

${ }^{2}$ Тернопольский национальный медицинский университет имени И. Я. Горбачевского МОЗ Украины, майдан Воли, 1, г. Тернополь, 46002, Украина

${ }^{3}$ Государственный научно-исследовательский контрольный институт ветеринарных препаратов и кормовых добавок, ул. Донецкая, 11, 79000, г. Львов, Украина

${ }^{4}$ Львовский национальный университет ветеринарной медицины и биотехнологий имени. С. 3. Гжицкого, ул. Пекарская 50, г. Львов, 79010, Украина

${ }^{5}$ Тернопольская опытная станция Института ветеринарной медицины НААН, ул. Троллейбусная, 12, г. Тернополь, 46027, Украина

\section{А Н Н О Т А ЦИ Я}

В статье представлена новая фармацевтическая композиция "Кальфомин” включающия макро- и микроэлементы в виде водорастворимых солей, а именно Кальций, Фосфор, Магний, Натрий, Калий, Железо, Марганец, Цинк, Кобальт и Медь. Также в состав препарата входять незаменимые аминокислоты - метионин и лизин. Препарат применяют для лечения и профилактики заболеваний коров, свиней, овец и коз, связанных с нарушением метаболизма перечисленных нутриентов (послеродового пареза, рахита у молодых животных, остеомаляции у старых животных). Лекарственное средство эффективно при аллергиях, токсикозах, послеродовой гемоглобинурии, пятнистой болезни, крапивнице, экзантеме, геморрагическом диатезе, гематурии и миоглобинурии; парезе вследствие дефицита Кальция 
или Фосфора различной этиологии. Рекомендовано "Кальфомин" в качестве вспомогательной терапии при отравлении Свинцом, Фтором или щавелевой кислоты, а для птицы для улучшения яйценосности. Препарат применяют для увеличения прироста живой массы животных на откорме, и тому подобное.

При введении лабораторным животным в желудок, внутришньоочеревно и подкожно, установлено, что препарат относится к IV классу токсичности согласно СОУ 85.2-37-736: 2011 и ГОСТ 12.1.007-76, то есть относится к малотоксичным веществам. Получены данные о существенном повышении уже на 3-и сутки общего Кальция, неорганического Фосфора, Цинка и Меди в сыворотке крови отельных коров, которым орально задавали "Кальфомин”. А на 14-е сутки активность этих элементов уже была в пределах физиологических норм. Оральное введение коровам “Кальфомину” в дозе 30 мл на 100 кг массы тела в течение 10 дней после отела предотвращает послеродовой парез. "Кальфомин" представляет интерес для ветеринарной медицины и поэтому целесообразно продолжить его дальнейшее клиническое исследование и стандартизировать показатели его качества.

Ключевые слова: ОРАЛЬНЫЕ ПРЕПАРАТЫ, МИНЕРАЛЫ, АМИНОКИСЛОТЫ, “КАЛЬФОМИН”, ПОСЛЕРОДОВОЙ ПАРЕЗ.

\section{Л I T Е P A T У P A}

1. Внутрішні хвороби тварин [текст]: підручник / В. І. Левченко, I. П. Кондрахін, В. В. Влізло та ін.; За ред. В. І. Левченка. - Біла Церква, 2001. - 544 с.

2. Патент на корисну модель № 103271 Україна, МПК 2015.01, А61К 31/00, А61К 31/185 (2006.01), А61К 31/195 (2006.01). Комплексний препарат для регуляції мінерального обміну “Кальфомін” [текст] / І. М. Дмитрієв, А. О. Лазуткіна, Р. М. Сачук, С. В. Жигалюк, І.М. Лук'яник; заявник і патентовласник Дослідна станція епізоотології IBM НАAН - № u 2015 05522; заявка 04.06. 2015; опубл. 10.12.2015; Бюл. № 23. - 4 с.

3. Снітинський В. В. Кількісна характеристика та ферментативна активність рубцевої мікрофлори у корів при використанні в складі сінажно-концентратних раціонів вдосконалених рецептів комбікормів та преміксів [текст] / В. В. Снітинський, Н. Г. Войтович// НТБ Державного науково-дослідного контрольного інституту ветеринарних препаратів та кормових добавок і Інституту біології тварин. - 2005. - Вип. 6, № 2. - С. 199-203.

4. Долецький С.П. Теоретичне та клініко-експериментальне обгрунтування профілактики порушень мінерального обміну в корів у біогеохімічних зонах України: дис. ... д-ра вет. наук : 16.00.01 [текст]. Долецький Станіслав Павлович. Нац. у-тет біоресурсів та природокористування України. - Київ. - 2015. - 38 с.

5. Токсикологічний контроль нових засобів захисту тварин: методичні рекомендації [текст] / М. В. Косенко, О. Г. Малик, І. Я. Коцюмбас та ін. - К., 1997. - 34 с.

6. Доклінічні дослідження ветеринарних лікарських засобів [текст] / І. Я. Коцюмбас, О. Г. Малик, І. П. Патерега та ін.; за редакцією І. Я. Коцюмбаса. - Львів : Тріада плюс, 2006. $360 \mathrm{c}$.

7. Биохимические методы исследований в клинике [текст] // под ред. А. А. Покровского// М. : Медицина, 1969. - 652 с.

8. Лабораторные исследования в ветеринарии: Справочник [текст] / Под ред. Б. И. Антонова // - М. : Агропромиздат, 1989. - 320 с.

9. Рокиикий П. Ф. Биологическая статистика [текст]. - Минск: Вышейшая школа, 1973. $-318 \mathrm{c}$.

10. Діагностика метаболічних зрушень в організмі корів у період сухостою та розробка превентивних заходів [текст] / Р. М. Сачук, О. А. Кацараба, О. Я. Дмитрів, Я. С. Стравський // Науковий журнал «Наукові горизонти». - Житомир, Житомирський національний агроекологічний університет, 2018. - № 9-10 (71). - С. 69-74. 


\section{References}

1. Levchenko V. I., Kondrakhin I. P., \& Vlizlo V. V. (2001). Vnutrishni khvoroby tvaryn. pidruchnyk. Bila Tserkva. (in Ukrainian).

2. Dmytriiev I. M., Lazutkina A. O., Sachuk R. M., Zhyhaliuk S. V., Lukianyk I.M. (2015) Patent na korysnu model № 103271 Ukraina, Kompleksnyi preparat dlia rehuliatsii mineralnoho obminu "Kalfomin"; Biul. № 23. - 4 s. (in Ukrainian).

3. Snitynskyi V. V., Voitovych N. H. (2005). Kilkisna kharakterystyka ta fermentatyvna aktyvnist rubtsevoi mikroflory u koriv pry vykorystanni v skladi sinazhno-kontsentratnykh ratsioniv vdoskonalenykh retseptiv kombikormiv ta premiksiv. Naukovo-tekhnichnyi biuleten Derzhavnoho naukovo-doslidnoho kontrolnoho instytutu veterynarnykh preparativ ta kormovykh dobavok $\mathrm{i}$ Instytutu biolohii tvaryn. 6, 2, 199-203. (in Ukrainian).

4. Doletskyi S. P. (2015). Teoretychne ta kliniko-eksperymentalne obgruntuvannia profilaktyky porushen mineralnoho obminu v koriv u bioheokhimichnykh zonakh Ukrainy: dys. d-ra vet. nauk : 16.00.01. Nats. u-tet bioresursiv ta pryrodokorystuvannia Ukrainy. Kyiv. 38 s. (in Ukrainian).

5. Kosenko M. V., Malyk O. H., \& Kotsiumbas I. Ya. (1997). Toksykolohichnyi kontrol novykh zasobiv zakhystu tvaryn: metodychni rekomendatsii. K. 34 s. (in Ukrainian).

6. Kotsiumbas I. Ya., Malyk O. H., \& Patereha I. P. (2006). Doklinichni doslidzhennia veterynarnykh likarskykh zasobiv. Lviv: Triada plius. (in Ukrainian).

7. Pokrovskoho A. A. (1969). Byokhymycheskye metodu issledovanyi v klynyke. M.: Medytsyna. (in Russian).

8. Antonova B. Y. (1989). Laboratornue issledovanyia v veterynaryy: Spravochnik. M.: Ahropromizdat. (in Russian). Russian).

9. Rokytskyi P. F. (1973). Byolohycheskaia statystyka. Mynsk: Vusheishaia shkola. (in

10. Sachuk R. M., Katsaraba O. A., Dmytriv O. Ya, \& Stravskyi Ya. S. (2018). Diahnostyka metabolichnykh zrushen $\mathrm{v}$ orhanizmi koriv u period sukhostoiu ta rozrobka preventyvnykh zakhodiv. Naukovyi zhurnal «Naukovi horyzonty». Zhytomyr, Zhytomyrskyi natsionalnyi ahroekolohichnyi universytet. 9-10 (71), 69-74. (in Ukrainian).

Рецензент - А. В. Лисиця, д. б. н., доцент, Дослідна станція епізоотології IBM НААН. 